\title{
PEMANFAATAN FUZZY INFERENCE SYSTEM UNTUK MENENTUKAN DAMPAK COVID-19 TERHADAP PEREKONOMIAN DI KOTA BATAM
}

\author{
Nanda Jarti \\ Teknik Informatika, Fakultas Teknik, Universitas Ibnu Sina \\ Email : nandaluthan@gmail.com
}

\begin{abstract}
Corona virus is a very dangerous virus and can kill human life. This virus causes minor illnesses and serious illnesses such as colds or colds, since the emergence of the Corona Virus or Covid 19 paralyzing all human activities carried out outside the home. The problem of this research is in the form of the impact of the corona virus on the economy, especially in the city of Batam so that the residents of Batam can overcome this corona virus outbreak to improve the weakening economy. The main objective of this research is to examine the impact of Covid 19 on the economy of the Batam population so that the Batam population can improve the already weakened economy. This study uses Fuzzy Inference Sistym the Mamdani Method for Decision Making, using Operators or through the process of Fuzification of Input Variables, Inference Machines to process rules and produce Defuzification to get the final value
\end{abstract}

Keywords: corona prediction fuzzy inference system; mamdani method

\begin{abstract}
Abstrak:Virus Corona merupakan sebuah virus yang sangat berbahaya dan bisa menghilangkan nyawa manusia. Virus ini mengakibatkan penyakit ringan dan penyakit berat seperti common cold atau pilek, Sejak munculnya Virus Corona atau Covid 19 melumpuhkan semua kegiatan aktivitas manusia yang dilakukan diluar rumah. Permasalahan Penelitian ini berupa dampak akibat virus corona terhadap perekonomian khususnya pada Kota Batam sehingga penduduk Batam bisa mengatasi Wabah Virus corona ini untuk meningkatkan perekonomian yang semakin melemah. Tujuan Utama Penelitian ini mengkaji Dampak akibat Covid 19 terhadap perekonomian penduduk batam sehingga penduduk Batam bisa meningkatkan perekonomian yang sudah melemah. Penelitian ini menggunakan Fuzzy Inference Sistem Metode Mamdani untuk Pengambilan sistem Keputusan, menggunakan Operator Or dan melalui proses Fuzifikasi penentuan Variabel Input, Mesin Inferensi untuk melakukan proses aturan dan menghasilkan Defuzifikasi untuk mendapatkan nilai akhir.
\end{abstract}

Kata Kunci : fuzzy inference sistem; metode mamdani; prediksi corona 
DOI : https://doi.org/ 10.33330/jurteksi.v7i3.1164

Available online at http://jurnal.stmikroyal.ac.id/index.php/jurteksi

\section{PENDAHULUAN}

Virus Corona berkembang pada awalnya di daerah Wuhan yang terjadi pada tanggal 30 Desember 2019 yang mana kota mengeluarkan sebuah pernyataan tentang pemberitahuan mendesak tentang pengobatan yang berhubungan dengan virus Corona. Proses Perpindahan Virus Corona sangat cepat sehingga terdapat 188 negara yang terkena Wabah virus ini. Penyebaran virus ini telah menyebar diseluruh dunia sehingga membawah dampak penurunan perekonoman di negara Indonesia diantaranya dibidang perdagangan, investasi pariwisata, penerbangan, pelayaran dan bidang lainnya [1]. China Merupakan negara yang mengirim barang ekspor yang paling besar di dunia. Kegiatan pengiriman barang baik dari dalam negeri maupun diluar negeri dikerjakan oleh negara china salah satunya adalah negara indonesia. Negara China juga termasuk negara mitra dagang terbesar yang dimiliki oleh negara indonesia. Awal muncul Virus Corona 19 menjangkit negara china berdampak sangat buruk bagi seluruh dunia khususnya negara indonesia. Dampak Virus Corona seperti menurunnya harga. Selain itu dampak virus Corona mengganggu proses sektor impor, ekspor, menghambat berbagai sektor mengakibatkan hasil dari pajak mengalami penurunan yang sangat drastis [2].

Pada setiap berita elektronik ditayangkan menjelskan bahwa virus Corona mengalami peningkatan jumlah kasus yang terjadi dalam waktu singkat serta membutuhkan sebuah penangan cepat.Sayangnya untuk detik ini belum ditemukan obat yang sangat berhasiat untuk menyelesaikan kasus virus Corona, Upaya pemerintah saat ini yaitu melakukan lockdown atau isolasi total atau karantina. Menurut UU Republik Indonesia Nomor 6 tahun 2018 Karantina menurut UU Republik Indonesia Nomor 6 tahun 2018 tentang Kekarantinaan Kesehatan adalah pembatasan kegiatan dan/atau pemisahan seseorang yang terpapar penyakit menular sebagaimana ditetapkan dalam peraturan perundangundangan meskipun belum menunjukkan gejala apapun untuk mencegah kemungkinan penyebaran ke orang di sekitarnya. Selain Itu pemerintah Menganjurkan agar penduduk indonesia itu melakukan perjalanan muduk pada Hari raya Idul Fitri untuk mengurangi Penyebaran Virus corona dengan cara menentup Akses perbangan dan melakukan penjagaan oleh aparat pada batas wilayah perjalanan Mudik [3]. Untuk meningkatkan perekonomian di Indonesia dibutuhkan kesadaran penduduk indonesia untuk menjaga protokol kesehatan agar virus corona tidak menyebar. Pemerintah telah mengeluarkan surat edaran Nomor H.K.02.01/MENKES/202/2020 [4]

Logika Fuzzy adalah sebuah ilmu yang menjelaskan tentang ketidakpastian. Logika Fuzzy ini juga mampu dalam menjelaskan sebuah pemetaan dalam suatu ruang input kedalam sebuah ruangan output.

Logika fuzzy memiliki kelebihan [5] diantaranya:

1. Pemahaman pada logika fuzzy menggunakan konsep yang sangat mudah dan sederhana untuk dimengerti

2. Sangat Fleksibel

3. Memiliki sebuah toleransi dalam data data

4. Mampu membuat fungsi fungsi non linear dengan lengkap

5. Bisa mengimplementasikan pengalaman para pakar tanpa melakukan sebuah pelatihan terlebih dahulu

6. Sistem fuzzy sudah melakukan 
kerjasama mengunakan teknik kendali dengan konvensional

7. Sistem Fuzzy menggunakan bahasa alami.

Metode Fuzzy terdiri dari empat bagian yaitu metode Mamdani, sugeno, tsukamoto dan tahani, Metode yang paling populer atau yang paling banyak dipakai oleh peneliti yaitu metode Mamdani, karena metode ini mudah untuk dipahami dan cocok dengan pembahasan kasus ini. Metode mamdani merupakan sebuah metode yang menggunakan nilai MAX-MIN atau nilai besar ke nilai terkecil. Untuk menyelesaikan sebuah kasus menggunakan metode Mamdani dibutuhkan empat langkah yaitu fuzzyfikasi ( menentukan variabel input atau ouput dibagi menjadi 1 atau lebih dari himpunan fuzzy) yang akan digunakan, Aplikasi fungsi implikasi berupa penentuan nilai yang akan digunakan, nilai yang dipilih merupakan nilai minimum atau nilai terkecil, Komposisi aturan berupa penentuan aturan yang akan digunakan dan terakhiryaitu defuzifikasi berupa nilai akhir menghasilkan nilai output.Dalam menyelesaikan sebuah penelitian logika fuzzy memiliki berbagai macam metode diantaranya metode mamdani,sugeno,tahani dan tsukamoto, masing masing penyelesaian metode mimiliki cara dan perhitungan yang berbeda. Persoalan ini timbul bagaimana cara menyelesaikan metode mamdani dalam memprediksi dampak perekonomian di indonesia akibat Virus Corona[6].

Himpunan fuzzy merupakan sebuah bentuk kelas objek dengan kontinum yang mempunyai nilai keanggotaan. Set ini bisa dicirikan kedalam mempunyai suatu keanggotaan yang ditandai dengan nilai nol dan satu atau istilah lai menggunakan "ya atau tidak selain itu menggunakan kata lain false dan true.

Dari berbagai sumber jurnal yang diperoleh dapat disimpulkan bahwa Himpunan fuzzy merupakan sebuah bentuk kelas objek yang memiliki nilai bersifat kontinum dari setiap nilai keanggotaan dengan memiliki ( Karakteristik ) memiliki nilai dari setiap anggota dengan posisi nilai 0 dan 1 [7]. Logika fuzzy merupakan sebuah bentuk Konsep yang sangat sederhana dan memiliki Karakteristik Matematika mampu menyelesaikan persoalan yang mengandung Ketidakpastian. Logika fuzzy bisa dijadikan sebagai Sistem Pengambilan Keputusan untuk mendapatkan nilai Akhir.

Untuk memahami Logika fuzzy ada beberapa hal yang harus dipahami seperti Himpunan fuzzy, Domain, Semesta Pembicaraan dan Range.[8]

Sistematis sebuah Sistem Inferensi Fuzzy yang harus dikerjakan, diantaranya :

1. Nilai Input.

Merupakan sebuah nilai (Crips) yang bersifat nyata atau pasti

2. Komposisi Fuzzy.

Sebuah Bentuk Proses yang mana harus mengubah nilai cripst input menjadi bentuk fuzzy yang menggunakan bentuk fungsui keanggotaan, dan setip variabel yang dipakai harus berbentuk fungsi keangotaan.

3. Aturan

Aturan dalam logika fuzzy dijadikan petunjut untuk memperoleh nilai hasil akhir.

4. Dekomposisi Fuzzy

Bentuk dari proses kerja yang mana mengganti kembai data fuzzy kedalam bentuk crips awal.

5. Nilai Output

Nilai Terakhir yang digunakan dalam 
menentukan keputusan. Fuzzy juga bisa diproses tanpa melalui proses komposisi aturan maupun defuzifikasi[9].

Fuzzy infernce system memiliki 3 operator untuk mendapatkan nilai output. Tiga operator yang dimiliki diantaranya:

1. Operator or

2. Operator and

3. Operator not

Pada sistem inferensi fuzzy bisa dijadikan sebagai sistem pengendali untuk aturan aturan fuzzy tersebut[7]. (FIS) mempunyai empat unit diantaranya

1. Unit fuzzifikasi (fuzzification unit).

2. Unit penalaran logika fuzzy (fuzzy logic reasoning unit).

3. Unit basis pengetahuan (knowledge base unit) yang bagian bagiannya :

a. Basis data (data base) Berisi tentang fungsi fungsi keanggotaan dan himpunan fuzzy yang berhubungan dengan niai linguistik yang digunakan.

b. Basis aturan (rule base) yang berisi tentang aturan aturan implikasi pada sebuah fuzzy.

4. Unit defuzzifikasi / unit penegasan (defuzzification unit).

Berdasarkan penelitian [10] Metode Mamdani merupakan sebuah metode yang pupuler saat ini, metode ini memakai nilai terbesar-terkecil atau lebih dikenal dengan istilah max-min untuk memperoleh nilai output.

\section{METODE}

Dalam menyelesaikan kasus ini, maka penelitian ini menggunakan metode Mamdani dengan mengambil nilai maxmin. Langkah langkah metode mamdani yaitu:

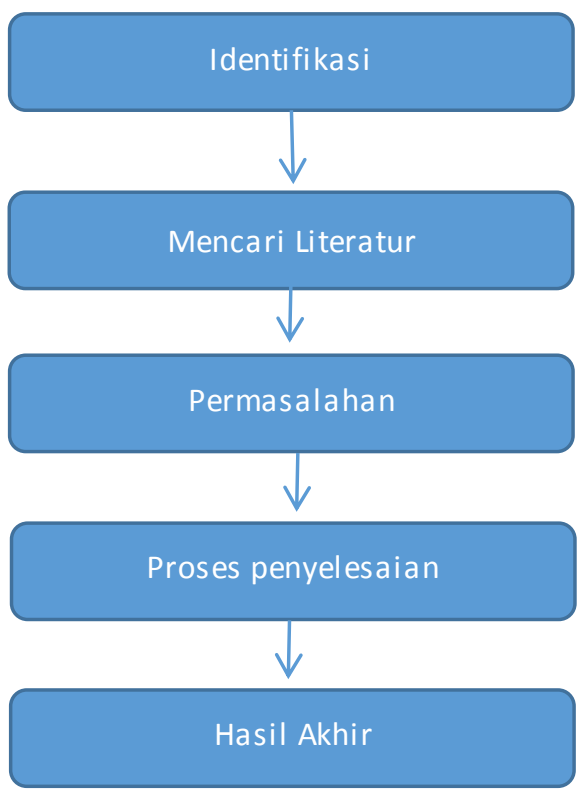

Gambar 1. Desain Penelitian

Proses penelitian ini harus dilakukan secara sistematis untuk mendapatkan hasil yang maksimal. Proses pertama yaitu menentukan variabel input dari data yang diperoleh, proses kedua menetukan masing masing nilai $\mathrm{x}$ yang akan diproses, langkah ketiga membuat Rule daari masing masing aturan berdasarkan variabel yang diperoleh dan langkah akhir berupa nilai $\mathrm{Z}$ untuk menghasilkan nilai Output.

\section{HASIL DAN PEMBAHASAN}

Tabel 1 menjelaskan tahap tahap penyelesaian dalam memprediksi perekonomian akibat Virus Corona. Data diperoleh dari berbagai sumber. Berdasarkan data maka dikelompokkan menjadi Empat variabel input dan satu variabel output. 
DOI : https://doi.org/ 10.33330/jurteksi.v7i3.1164

Available online at http://jurnal.stmikroyal.ac.id/index.php/jurteksi

Tabel 1. Variabel Fuzzy

\begin{tabular}{lc}
\hline Variabel & $\begin{array}{l}\text { Himpunan } \\
\text { Fuzzy }\end{array}$ \\
\hline Manufaktur & {$\left[\begin{array}{ll}0 & 60\end{array}\right]$} \\
\hline Sektor Parawisata & {$\left[\begin{array}{ll}0 & 60\end{array}\right]$} \\
\hline Pusat Perbelanjaan & {$\left[\begin{array}{ll}0 & 80\end{array}\right]$} \\
\hline $\begin{array}{l}\text { Industri Sektor } \\
\text { Jasa }\end{array}$ & {$\left[\begin{array}{ll}0 & 100]\end{array}\right.$} \\
\hline
\end{tabular}

Implementasi fuzzy kedalam Software Matlab

1. Variabel Manufaktur

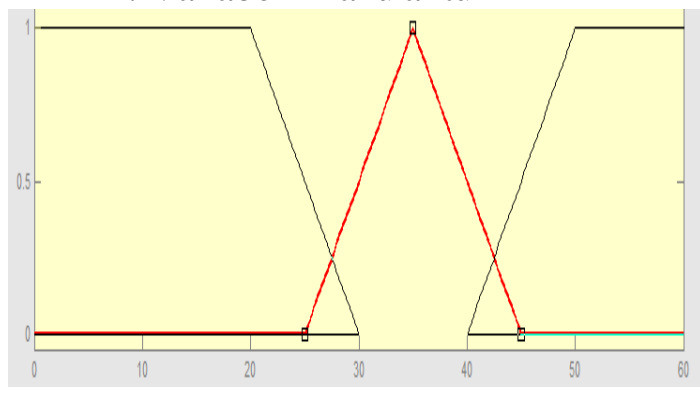

Gambar 2. Keanggotaan Manufaktur

2. Variabel Parawisata Pusat

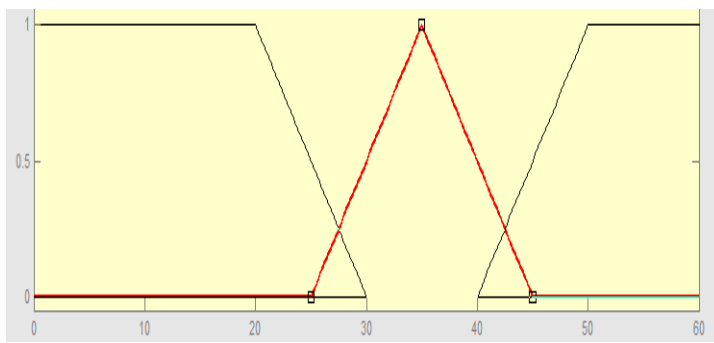

Gambar 3. Keanggotaan Parawisata Pusat

3. Variabel Pusat Perbelanjaan

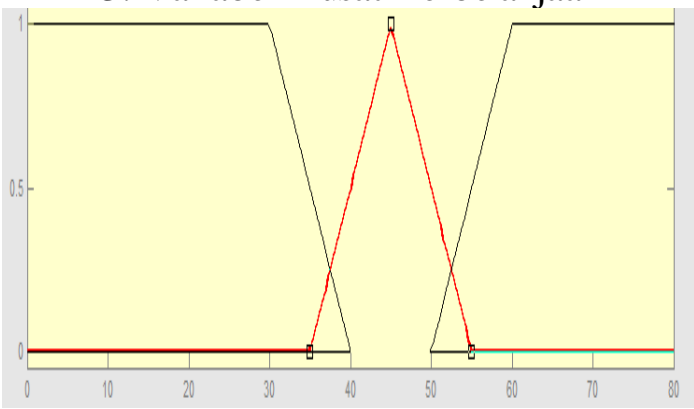

Gambar 4. Keanggotaan Pusat Perbelanjaan
4. Industri Sektor Jasa

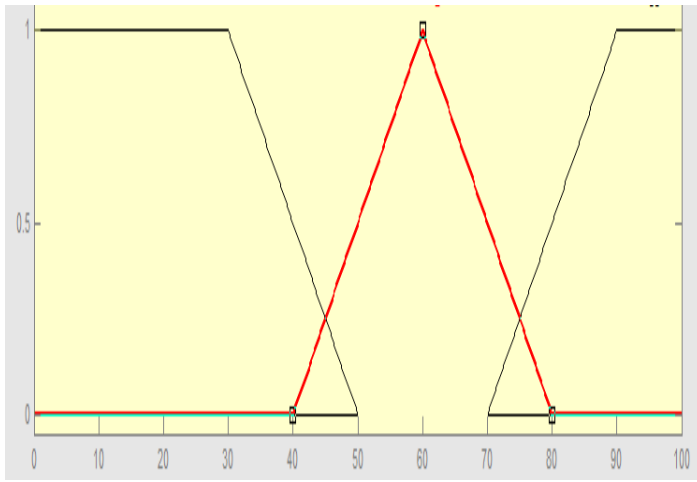

Gambar 5. Keanggotaan Sektor Jasa

5. Variabel Output

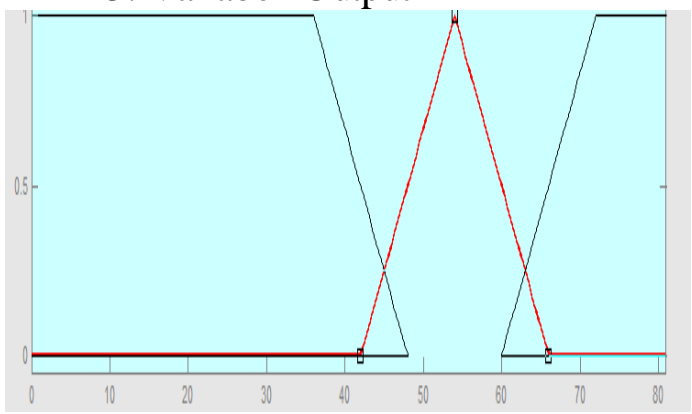

Gambar 6. Derajat Keanggotaan Output

Implementasi penyelesaian kasus untuk menghitung prediksi pekeronomian di Kota Btatam.

Untuk memperoleh nilai defuzifikasi (Output) diperlukan proses dalam pencarian nilai $X$ yang mana nilai variabel Input : Manufaktur = 29,5; Parawisata Pusat $=28$; Pusat Perbelanjaan $=43$; Industri Sektor Jasa $=$ 70.

a. Indikator Manufaktur, dibagi kedalam 3 himpunan fuzzy, diantaranya tinggi(T), rendah(R), $\operatorname{sedang}(\mathrm{S})$, diketahui Variabel Manufaktur 29,5, maka proses penyelesaian nya adalah :

$$
\begin{aligned}
& \mu \text { Rendah }(\mathrm{R})[29,5] \\
&=[\mathrm{b}-\mathrm{x}] /[\mathrm{b}-\mathrm{a}] \\
&=[31-29,5] /[31-20] \\
&=1,5 / 11 \\
&=0,13
\end{aligned}
$$


DOI : https://doi.org/ 10.33330/jurteksi.v7i3.1164

Available online at http://jurnal.stmikroyal.ac.id/index.php/jurteksi

$\mu$ Sedang(S) [29,5]

$$
\begin{aligned}
& =[\mathrm{x}-\mathrm{a}] /[\mathrm{b}-\mathrm{a}] \\
& =[29,5-25] /[35-25] \\
& =5 / 10 \\
& =0,45
\end{aligned}
$$

$\mu$ Tinggi(T) $[29,5]=0$

b. Indikator Parawisata Pusat, dibagi kedalam tiga himpunan, diantaranya banyak(B), sedikit(S) dan sedang(S). diketahui Variabel Parawisata Pusat sebesar 27, Proses penyelesaian nya adalah:

$$
\begin{aligned}
\mu \text { Sedikit(S) }[28] \\
\quad=[\mathrm{b}-\mathrm{x}] /[\mathrm{b}-\mathrm{a}] \\
=[30-28] /[30-20] \\
=2 / 10 \\
\quad=0,2
\end{aligned}
$$

$\mu$ Sedang(S)[28]

$$
\begin{aligned}
& =[\mathrm{x}-\mathrm{a}] /[\mathrm{b}-\mathrm{a}] \\
& =[28-25] /[35-25] \\
& =3 / 10 \\
& =0,3
\end{aligned}
$$

$\mu$ Banyak (B) [28] $=0$

c. Indikator Pusat Perbelanjaan, dibagi menjadi Tiga himpunan, yaitu Sedang(S) Sedikit(S) dan Banyak(B). diketahui Variabel Pusat perbelanjaan sebesar 42, maka proses penyelesaian nya adalah:

$$
\begin{aligned}
& \mu \text { Sedikit(S) }[43] \quad=0 \\
& \begin{aligned}
\mu \text { Sedang(S) }[43] \\
\quad=[\mathrm{x}-\mathrm{a}] /[\mathrm{b}-\mathrm{a}] \\
\quad=[43-35] /[45-35] \\
\quad=8 / 10 \\
\quad=0,8
\end{aligned}
\end{aligned}
$$

$\operatorname{Banyak}(\mathrm{B})[43]=0$

d. Indikator Industri Sektor Jasa, dibagi menjadi 3 himpunan fuzzy, yaitu
Tinggi(T), Rendah(R), dan Sedang(S). diketahui Variabel Industri Sektor Jasa 69, maka proses penyelesaian nya adalah :

$$
\mu \operatorname{Rendah}(\mathrm{R})[70] \quad=0
$$

$$
\begin{aligned}
\mu \text { Sedang }(\mathrm{S})[70] \\
=[\mathrm{c}-\mathrm{x}] /[\mathrm{c}-\mathrm{b}] \\
=[80-70] /[80-60] \\
=10 / 20 \\
=0,5
\end{aligned}
$$

$\mu$ Tinggi(T) $[70] \quad=0$

Setelah proses pertama langkah kedua yaitu menerapkan fungsi implikasi dengan memperoleh modifikasi input dengan memakai aturan rule yang akan diproses.Nilai yang digunakan adalah nilai Min yang berpengaruh dengan nilai derjaat keanggotaan.

[R5] if Manufaktur RENDAH, and Parawisata Pusat SEDIKIT, and Pusat Perbelanjaan SEDANG, and Industri Sektor Jasa SEDANG, then Prediksi MENURUN.

[R14] if Manufaktur RENDAH, and Parawisata Pusat SEDANG, and Pusat Perbelanjaan SEDANG, and Industri Sektor Jasa SEDANG, then Prediksi MENURUN.

[R132] if Manufaktur SEDANG, and Parawisata Pusat SEDANG, and Pusat Perbelanjaan SEDANG, and Industri Sektor Jasa SEDANG, then Prediksi MENURUN.

[R141] if Manufaktur SEDANG, and Parawisata Pusat SEDANG, and Pusat Perbelanjaan SEDANG, and Industri Sektor Jasa SEDANG, then Prediksi SEDANG. 
Langkah selanjutnya yaitu mencari komposisi aturan dengan menggunakan metode (Max) sehingga memperoleh derajat kebenaran dengan proses :



Gambar 7 . Daerah Hasil Komposisi

Langah terakhir yaitu defuzifikasi nilai output yang diperoleh dari komposisi aturan. Proses ini menggunakan metode Centroid, dengan menghitung monen setiap daerah yang digunakan.

Setelah kita melakukan semua proseslangkah selanjutnya mencari luas pada masing masing daerah fuzzy

$$
\begin{aligned}
\text { A1 } & =46,4 * 0,35 \\
& =16,24 \\
\text { A2 } & =\left((0,35+0,15)^{*}(46,6-46,4)\right) / 2 \\
& =(0,5 * 0) / 2 \\
& =0,25 \\
\text { A3 } & =(66-46,6) * 0,15 \\
& =19,4 * 0,15 \\
& =59,01
\end{aligned}
$$

Nilai pada Titik Pusat diantaranya :

$$
\begin{aligned}
\mathrm{Z} & =\frac{300,704+14,674+327,664}{13,92+0,5+3,88} \\
& =\frac{643,042}{18,3} \\
& =35,13
\end{aligned}
$$

Nilai Akhir yang diperoleh dari pencarian Defuzifikasi sebesar 35,13 yang berada pada Range Menurun. Dengan demikian logika fuzzy ini dapat dijadikan sebagi sistem pengembilan keputusan dalam menentukan perekonomian di Kota Batam. Untuk mencari nilai yang lain tinggal memasukkan nilai $\mathrm{X}$ kedalam logika fuzzy untuk mendapatkan hasil Akhir.

\section{SIMPULAN}

Metode mamdani pada logika fuzzy dapat digunakan dalam memprediksi perekonomian di kota Batam. Metode Mamdani mampu mempermudah dalam Pengambilan sebuah keputusan dengan melihat kriteria input yang diperoleh seperti Variabel Manufaktur, Parawisata Pusat, Pusat Perbelanjaan, Industri Sektor Jasa. Untuk memperoleh hasil Prediksi perekonomian, berdasarkan data dan hasil Pengolahan Perekonomian Kota Batam berada pada range Menurun.

\section{DAFTAR PUSTAKA}

[1] A. Ikhwan, "Penerapan Fuzzy Mamdani Untuk Sistem Pendukung Keputusan Pemilihan Laptop," J. Fasilkom, vol. 9, no. 2, pp. 476-483, 2019, doi: 10.37859/jf.v9i2.1407.

[2] D. A. D. Nasution, E. Erlina, and I. Muda, "DAMPAK PANDEMI COVID-19 TERHADAP PEREKONOMIAN INDONESIA," J. Ekon. Perjuangan, vol. 2, no. 2, pp. 212224, 2020, doi: 10.36423/jumper.v2i2.665.

[3] N. Mona, 'Konsep Isolasi Dalam Jaringan Sosial Untuk Meminimalisasi Efek Contagious (Kasus Penyebaran Virus Corona Di Indonesia)," J. Sos. Hum. Terap., vol. 2, no. 2, pp. 117-125, 2020, doi: $10.7454 /$ jsht.v2i2.86.

[4] F. D. A. Pinasti, "Analisis Dampak Pandemi Corona Virus Terhadap Tingkat Kesadaran Masyarakat dalam Penerapan Protokol Kesehatan," Wellness Heal. Mag., vol. 2, no. 2, pp. 237-249, 2020, doi: 10.30604/well.022.82000107. 
DOI : https://doi.org/ 10.33330/jurteksi.v7i3.1164

Available online at http://jurnal.stmikroyal.ac.id/index.php/jurteksi

[5]

T.
"PERANCAngabowo,
KENDALI VALVE DENGAN
ALGORITMA LOGIKA FUZZY
MENGGUNAKAN BAHASA
VISUAL BASIC," vol. 6, no.
March, pp. 123-135, 2015.

[6] D. L. Rahakbauw, F. J. Rianekuay, and Y. A. Lesnussa, "Penerapan Metode Fuzzy Mamdani Untuk Memprediksi Jumlah Produksi Karet (Studi Kasus: Data Persediaan Dan Permintaan Produksi Karet Pada Ptp Nusantara Xiv (Persero) Kebun Awaya, Teluk Elpaputih, MalukuIndonesia)," J. Ilm. Mat. Dan Terap., vol. 16, no. 1, pp. 51-59, 2019, doi: 10.22487/2540766x.2019.v16.i1.1 2764.

[7] L. Muthoharoh, M. P. Pamungkas, R. P. Sari, J. T. Elektro, F. Sains, and U. N. Ulama, "Penerapan Program Software Matlab dalam Memecahkan Permasalahan
Rangkaian Listrik: Pemodelan Dinamika Sistem Kapasitor dan Induktor ( Prinsip Nilai Eigen dan Vektor Eigen )," vol. 10, no. 3, pp. 303-309, 2021.

[8] S. Aymé, B. Dallapiccola, and D. Donnai, "Orphanet Journal of Rare Diseases: Launch editorial," Orphanet J. Rare Dis., vol. 1, no. 1, pp. 2-3, 2006, doi: 10.1186/17501172-1-1.

[9] A. Sukoco and R. Yuli Endra, "PENERAPAN FUZZY INFERENCE S YS TEM METODE MAMDANI UNTUK PENENTUAN BESARAN PERSENTASE BEASISWA," $J$. Manaj. Sist. Inf. dan Teknol., pp. 89-99, 2016.

[10] D. Vinsensia and Y. Utami, "Penerapan Fuzzy Inference System (FIS) Metode Mamdani dalam Pemilihan Jurusan Perguruan Tinggi," Publ. J. Penelit. Tek. Inform., vol. 2, no. 2, pp. 2836, 2018. 